\title{
Chinese Film Industry Under the Lens of Copyright, Policy, and Market
}

\author{
Lizhou Wei and Yanbing Li
}

\section{Abstract}

The development history of the Chinese film industry can generally be divided into three stages: early cinema, policy-controlled cinema, and contemporary cinema. The Chinese cinema is an instructive story. On the one hand, it had been under the radar of the copyright law for 95 years, and its main constraints were underdeveloped technology, private capital deficiency, wartime disruption, and ideological and political concerns. On the other, contemporary Chinese film copyright has been greatly influenced by both the author's right system and the copyright system. Despite high piracy and weak enforcement, it managed to complete a dramatic shift from a policy-controlled to market-driven and even copyright-based industry within just decades. This chapter will place the film industry under the lens of copyright, policy, and market in the context of China.

Keywords

Film industry $\cdot$ Marketization $\cdot$ Industrialization $\cdot$ Film policy $\cdot$ Film copyright

\section{Early Cinema (1896-1930)}

The early cinema in China consisted of two periods - the last 15 years of the Qing Dynasty and the golden age of the silent films. Shortly after Louis Lumière brothers' first commercial public screening in Paris back in 1895, motion pictures made

L. Wei $(\bowtie)$

Zhejiang University, Guanghua Law School, Hangzhou, China

Y. Li

Shanghai University of Finance and Economics, School of Law, Shanghai, China 
their first public appearance in Shanghai in $1896 .{ }^{1}$ Ten years later, the first Chinese film was produced by a Chinese photo studio, which recorded selected parts of the Beijing opera "The Battle of Ding Jun Mountain" in $1905 .{ }^{2}$ Although the early movies were greatly constrained by the undeveloped economy and cinematographic technology, the public showed great interest in this new media, which combined traditional arts with entertainment. ${ }^{3}$ This alarmed the Qing government. ${ }^{4}$ As the first regulation on films in China, the provisions of the 1911 Shanghai Cinema Regulation focused on cinema administration, such as cinema permits, screen time, and seat arrangement, rather than corrective measures in connection with the content of the films. ${ }^{5}$ With the Revolution of 1911 putting an end to Chinese feudalism, China stepped into the period of the Republic of China in 1912. ${ }^{6}$ While European countries were heavily involved in World War I (1914-1918), the Chinese cinema together with industry and commerce under national capitalism was able to catch up and develop. Shanghai became the center of the early Chinese cinema. ${ }^{7}$

Early filmmaking in China primarily began with recording traditional Chinese operas. ${ }^{8}$ The first-generation Chinese directors actively involved themselves in experimenting with short fiction films adapted from modern plays. ${ }^{9}$ These efforts not only accumulated the filmmaking skills and private capital for further development but also cultivated professionals and strengthened the ability of motion pictures to elevate from faithfully recording spectacular attractions to visualizing expressive narrations. ${ }^{10}$ Motion pictures possessed the potential to reflect social reality and convey messages through cinematographic language to the audiences in a less preaching and yet very influential way. ${ }^{11}$ However, this led to divergences among filmmakers in defining the primary function of films as either leisure entertainment or moral cultivation. For example, as two representatives of the first generation of Chinese directors, while Zheng Zhengqiu deeply believed in "serious feature plays" that could "express critical opinions for social revolution and public

\footnotetext{
${ }^{1}$ Zhang (2004), 14.

${ }^{2}$ Cheng et al. (1998), 13-14.

${ }^{3}$ Lu and Shu (1998), 6.

${ }^{4}$ At the 70th birthday ceremony of Empress Dowager Cixi in 1904, a film projector exploded during screening. Cixi therefore treated film as unsafe and ominous and banned film screening in the prohibited palace after that. Cheng et al. (1998), 10.

${ }^{5}$ The Cinema Regulation was adopted by the Shanghai Municipal Public Office in 1911, before the end of the Qing Dynasty, followed by Shanghai City Hall during the early period of the Republic of China. Cheng et al. (1998), 11.

${ }^{6}$ The Republic of China (ROC) was established in 1912 and originally based in mainland China. It was governed by the Beiyang Government (northern warlords of China) from 1912 to 1926 and by the Kuomintang (KMT) Government from 1927 to 1949.

${ }^{7} \mathrm{Lu}$ and Shu (1998), 6. Wang (2001), 218.

${ }^{8}$ Lu and Shu (1998), 2; Zhang (2004), 15-16.

${ }^{9}$ The short fiction films emerged and developed from 1913 to 1922. Lu and Shu (1998), 6-10.

${ }^{10} \mathrm{Lu}$ and Shu (1998), 8. Zhang (2004), 16-37.

${ }^{11}$ Wang (2001), 205.
} 
education," Zhang Shichuan was solely motivated by box office considerations and emphasized pure entertainment. ${ }^{12}$

The Chinese cinema entered its first golden age in the mid-1920s, when silent films reigned. ${ }^{13}$ However, this golden age did not last long. The shortage of private capital weakened filmmakers' ability to explore new themes or genres that were yet to be accepted by the market. As a result, three types of commercial films - the history drama, martial arts movies, and movies of immortals and demons - flooded the market from 1926 to $1930 .{ }^{14}$ Movies were filled with violent, sexual, and vulgar content, cheap dream-making, visual sensation, and attractiveness. Destructive market competition not only accelerated the downfall of the once thriving film industry but also invoked moral panic about the film content. In particular, criminal cases were reported to have dramatically increased after the import of a series of American detective films after World War I, as well as the release of domestic detective films, such as Yan Ruisheng, ${ }^{15}$ because detailed film scenes had allegedly become the textbooks for crimes. ${ }^{16}$ Chinese audiences even protested and called for banning foreign films, which often connected the image of Chinese with murderers, the intellectually disabled, drug addicts, or other indecent characters. ${ }^{17}$

Considering the negative impact of films on public security and social mores, as well as the growing nationalism and patriotism, the Education Committee in Jiangsu province was the first to establish a local Film Censorship Committee in 1923, which heralded the beginning of the film censorship system in China ${ }^{18}$ and adopted a single and yet unclear criterion of whether the content violated standards of morality and decency. ${ }^{19}$ Then, the Film Review Committee was established in Beijing for the central government in 1926 by the General Education Board, ${ }^{20}$ which expanded the review criteria from "immorality and indecency" to include "public security," "obscenity," "social mores," and "disgrace on Chinese and other content that would prejudice other countries' diplomatic relations with China." ${ }^{21}$ However, as the then

\footnotetext{
${ }^{12}$ Zheng and Zhang found a balance between profit-making and social enlightening in their film "Orphan Rescues Grandfather," which was the first film that gained both artistic and market success in 1923, Zhang (2004), 23-28.

${ }^{13}$ Lu and Shu (1998), 11-16.

${ }^{14} \mathrm{Lu}$ and Shu (1998), 25-31; Zhang (2004), 37-47.

${ }^{15}$ The motion picture department of Commercial Press made the first full-length feature film, "Yan Ruisheng," in 1921 based on a criminal case which happened in Shanghai in 1920. The makers of this detective film conducted bold experiments and tried to present the original circumstances of the case with rather brutal scenes. Wang (2001), 206-208; Li and Hu (1996), 67-71; Cheng et al. (1998), 44, 58-59.

${ }^{16}$ Wang (2001), 206.

${ }^{17}$ Wang (2001), 206-208, 216.

${ }^{18}$ Wang (2001), 216.

${ }^{19}$ Wang (2001), 217.

${ }^{20}$ The General Education Board was established in 1915, consisting of members commissioned by the education ministry, Beijing Police Department, university professors, and other specialists, Wang (2001), 212.

${ }^{21}$ Wang (2001), 220-221.
} 
Beiyang Government's reach did not extend much beyond Beijing, the actual coverage of the Film Review Committee was limited. ${ }^{22}$ The initial film censorship in China was decentralized, unofficial, non-binding, and ex post, with particular emphases on the moral cultivation and public education functions of film. ${ }^{23}$

While films had long been subject to control and regulations since introduction to China, there was no copyright law at all in China at the time when copyright protection was for the first time accorded to cinematographic productions in 1908 as literary or artistic works at the Berlin Conference of the Berne Convention. ${ }^{24}$ China in the 1920s generally considered copyright protection and accession to the Berne Convention unnecessary and even harmful to the progress of education, culture, and knowledge. ${ }^{25}$ When the first copyright statute was adopted in 1910 , the protected subject matter only covered literary works, works of fine arts, photographs, etc. ${ }^{26}$ excluding motion pictures from copyright protection. The 1928 Copyright Act of the Republic of China (ROC) ${ }^{27}$ also did not include films in the non-exclusive list of copyrightable work categories under Article $1 .{ }^{28}$

\section{Wartime Cinema (1930-1949)}

Due to the Japanese invasion of China in 1930-1945 and the civil war that immediately followed (1945-1949), China entered a 19-year period of wartime cinema while transiting from silent to sound films in the $1930 \mathrm{~s},{ }^{29}$ and the dramatic social unrest and national crisis turned Chinese cinema into a political and ideological battlefield ${ }^{30}$ In dealing with the emergence of leftist films and the following largescale "Left-wing Cinema Movement" (1932-1937), ${ }^{31}$ the KMT Government set up centralized, mandatory, and nationwide film censorship as a significant part of its

\footnotetext{
${ }^{22}$ Wang (2001), 221-222.

${ }^{23}$ Wang (2001), 218-219 and 223.

${ }^{24}$ Article 14(1)(2) of the Berne Convention Berlin Act 1908, Ricketson and Ginsburg (2005), para 8.31-8.41, Kamina (2016), 16-18. For the history of film protection in European countries prior to the Berne Convention Berlin Revision 1908, see Kamina (2016), 7-16.

${ }^{25}$ Shanghai publishers petition against acceding to the Berne Convention, Shanghai Xin Wen Bao, 8 December 1920, cited from Zhou and Li (1997), 151-153.

${ }^{26}$ The Copyright Law of the Qing Dynasty, adopted in 1910, was the very first copyright act in Chinese history and was replaced by the Copyright Law of the Beiyang Government in 1915.

${ }^{27}$ Copyright Act of ROC, adopted by the Nationalist Government in 1928.

${ }^{28}$ Arguably, film scripts could be protected as literary works by then already; see Zhou and Li (1997), XII.

${ }^{29} \mathrm{Lu}$ and Shu (1998), 37-39.

${ }^{30}$ Zhang (2004), 58; Lu and Shu (1998), 39.

${ }^{31}$ The leftist films refer to "those anti-imperialist, anti-feudal films produced between 1933 and 1935 by the leftist film movement engineered by the underground Communist film group under the leadership of the Cultural Alliances of Chinese Leftists"; and "the term should be extended to include films released in 1937, and the movement's starting date be pushed back to account for film criticism that anticipated the emergence of leftist films," Zhang (2004), 63 and 66.
} 
overall scheme of national cultural policy and ideological control. ${ }^{32}$ The Film Censorship Law was adopted in 1930, and the Film Censorship Committee (FCC) was established in 1931 to consolidate the ideological domination of the Three Principles of the People - the Principle of Nationalism, Principle of Democracy, and Principle of People's Livelihood. ${ }^{33}$ The film censorship applied to both domestic and imported films and deployed four criteria to prohibit: (1) films giving humiliating portrayals of the Chinese people, (2) films opposing the Three Principles of the People, (3) films corrupting good traditions and customs or impairing public order, and (4) films advocating superstition and heresy. ${ }^{34}$

At its initial stage from 1931 to 1934, the FCC conducted film censorship primarily from the social and moral aspects based on the third and fourth criteria. Many domestic films of martial arts and fantasy subjects that advocated "superstition" 35 and some domestic and foreign films that featured "obscene sensuality" 36 were banned or required to edit or delete certain content before screening. While the FCC's censorship accelerated the death of the ill-timed commercial films, it did not engage in direct interference in film production. ${ }^{37}$ To minimize the "huge losses" because of banning films, in particular to the small film studios which already were suffering great financial hardships due to the wartime, the FCC allowed the release of some "problematic" films after necessary cuts and changes. ${ }^{38}$ Also, the FCC even showed some "sympathy for or tolerance of" certain leftist films, because the FCC was under the Ministry of Education, not the KMT Party, and was thus "less politically sensitive." ${ }^{39}$ Later, the Central Film Censorship Committee (CFCC) was established in 1934 under direct supervision of the Film Industry Guidance Committee of the KMT Central Propaganda Committee, ${ }^{40}$ which was more politically oriented, to strengthen the Nationalist government's ideology, and it adopted much stricter criteria to "block those 'ideologically incorrect' films," namely, the "left-wing films." 41

After the outbreak of Japan's full-scale invasion of China on July 7, 1937, the Film Censorship Law and the CFCC became ineffective in the areas occupied by Japan. ${ }^{42}$ Throughout the occupation, the Japanese military and its puppet

\footnotetext{
${ }^{32}$ Wang (1997), 60-61.

${ }^{33}$ Wang (2006), 141.

${ }^{34}$ Film Censorship Law, Articles 1 and 2. Wang (1997), 61, the English text cited from Wang (2006), 144.

${ }^{35}$ It was reported that $70 \%$ of the domestic films banned by the FCC in the first 3 years were films of martial arts and fantasy subjects, Wang (1997), 63.

${ }^{36}$ Wang 1997, 62-64; Wang (2006), 141 and 148.

${ }^{37}$ Priest (2015), 26.

${ }^{38}$ Zhang (2004), 70.

${ }^{39}$ Zhang (2004), 70, and Wang (2006), 142.

${ }^{40}$ Wang (1997), 66. Wang (2006), 144.

${ }^{41}$ Wang (1997), 66. Wang (2006), 143-145,149.

${ }^{42}$ Wang (2006), 150.
} 
governments ${ }^{43}$ adopted film censorship to mollify the Chinese awareness and suppress any nationalist flames of resistance ${ }^{44}$ and even became active and monopoly players themselves in producing and screening propaganda films in the occupied areas. $^{45}$

\section{$3 \quad$ Socialist Cinema (1949-1978)}

Socialist cinema started from the founding of the People's Republic of China (PRC) in 1949 and ended with the beginning of reform and opening up in 1978. Cinema was chosen by the Communist Party of China (CPC) as an essential part of the people's revolution and a construction pillar of socialist China. In comparison to the early and wartime cinema, socialist cinema was centrally planned and subordinated to politics. ${ }^{46}$

\subsection{State-Owned and Policy-Controlled Cinema}

On the one hand, taking reference of the Soviet Union model, ${ }^{47}$ a national studio system, within which movies were exclusively produced by state-owned studios and based on state funding and planning, was formed and lasted for almost half a century until its disintegration by the end of the twentieth century. ${ }^{48}$ For film distribution and exhibition, the Central Film Bureau (CFB) was put in place in 1949 to take charge of the nationwide distribution, display, export, and import of films and of supervising films before screening. ${ }^{49} \mathrm{Up}$ to 1958 , the state-owned China Film Corporation (CFC) monopolized the nationwide film distribution and exhibition, with a dual function of administrative governance and business management. ${ }^{50}$ Although the state-run studios and the CFC operated as an industry after the pattern of business management, the production and distribution of films were not market based at all. ${ }^{51}$

On the other hand, the socialist cinema was entirely policy-controlled, ${ }^{52}$ which for the first three decades of the PRC was neither stable nor systematic, but capricious, and followed the zigzag pattern of political campaigns, struggles between

\footnotetext{
${ }^{43}$ In occupied territory of China, Japan established the Wang Jingwei Government in Nanjing and the state of Manzhouguo in Northeast China.

${ }^{44}$ Wang (2002), 48-49.

${ }^{45}$ Wang (2002), 25-27, 45-48; Zhang (2004), 84.

${ }^{46} \mathrm{Hu}$ and Yao (1989), 7.

${ }^{47}$ Liu (2009), 7.

${ }^{48}$ Yin and Ling (2002), 2-3. Hu and Yao (1989), 14-15.

${ }^{49}$ Zhang (2004), 190-191.

${ }^{50} \mathrm{Li}$ (2017), 6-19.

${ }^{51} \mathrm{Hu}$ and Yao (1989), 15.

${ }^{52} \mathrm{Hu}$ and Yao (1989), 8-11. Jin (2014), 73-78.
} 
classes and cultural turbulence. ${ }^{53}$ Too often, the overemphasis on the ideological and instrumental function of the movie kept compressing the artistic latitude of filmmakers. ${ }^{54}$ It is hardly possible for filmmakers to maintain balance between artistic creation and political needs. ${ }^{55}$ During the Cultural Revolution (1966-1976), ${ }^{56}$ the most aggressive film policy was adopted, which conceptualized and standardized the fundamental principles for filmmaking ${ }^{57}$ and the rules for film shooting ${ }^{58}$ and imposed them on all filmmakers, ${ }^{59}$ which clearly violated the basics of artistic creation and cultural goods production. As a result, Chinese cinema suffered a decade of "devastation." ${ }^{60}$ It was with the end of the Cultural Revolution in 1976 that film production and distribution gradually resumed. ${ }^{61}$

\subsection{Film Copyright Remained Unattended}

During the age of policy-controlled cinema in China, international film copyright made tremendous progress. Cinematographic works, including assimilated works expressed by a process analogous to cinematography, have been explicitly enumerated as a category of "literary and artistic works" in Article 2(1) of the Berne Convention at the Brussels Revision in $1948 .{ }^{62}$ Following the international trend, the amendment of the Copyright Act of the ROC in 1944 for the first time recognized motion pictures as a category of copyrightable works, ${ }^{63}$ granting the copyright owner of films the exclusive right of public performance or rehearsal for a protection

\footnotetext{
${ }^{53}$ Zhang (2004), 189.

${ }^{54}$ Yin and Ling (2002), 10.

${ }^{55}$ Yin and Ling (2002), 19-20.

${ }^{56}$ During the Cultural Revolution, film production and criticism were not a matter of art or business but a purely political concern. In particular, films that were produced in the previous 17 years were disapproved as "evil films," The Development History of the Chinese Film authored by Cheng Jihua was labeled as the most anti-socialist book about film theory and criticism, filmmaking and technical professionals were dismissed, and the Beijing Film Academy was forced to close. Yin and Ling (2002), 84-85; Zhang YJ, 217.

${ }^{57}$ The fundamental principles for filmmaking during this period were the "three principles of prominence," that is, "give prominence to positive characters among all the characters, to heroes among the positive characters, and to the principal hero among the heroes," Zhang (2004), 219; Yin and Ling (2002), 86-87.

${ }^{58}$ Specific rules for film shooting had been compulsorily standardized as follows: "In frame composition, the hero must be located at the center and the villain at the fringes; in camera positioning, the hero must be shot from a low angle and the villain from a high angle; in proportions, the hero must appear large and the villain small; in color scheme, the hero must be bathed in warm colors and the villain in cold tones; in lighting, the hero must be bright and the villain dark," Zhang (2004), 219; Yin and Ling (2002), 90-92.

${ }^{59} \mathrm{Jin}(2014), 88-92$.

${ }^{60}$ Zhang (2004), 217.

${ }^{61}$ Jin (2014), 108-109.

${ }^{62}$ Ricketson and Ginsburg (2005), para 8.31.

${ }^{63} 1944$ Amendment of the Copyright Act of the ROC, Article 1 (1) No. 4.
} 
term of 10 years.$^{64}$ However, this Copyright Act was not very operational due to the Sino-Japan war, and became obsolete upon the founding of the PRC in 1949, which did not protect films until the first copyright law entered into force in 1991. In a word, copyright concerns with motion pictures remained unattended during the period of policy-controlled cinema in China, and movies functioned as important political and ideological tools for propaganda instead of cultural or entertainment products.

\section{Contemporary Cinema (1979-Present)}

After the 3rd Plenary Meeting of the 11th Central Committee of the CPC (CCCPC) in 1978 ushered China back on the course of economic reform and modernization, ${ }^{65}$ Chinese cinema entered into a new era of contemporary cinema with three phases recovery period of internal reform (1979-1990), transitional period of marketization (1990-2000), and industrialization (2001-present).

\subsection{Recovery Period of Internal Reform}

From 1979 to 1990 , Chinese cinema embarked on a period of internal reform. The national policy of economic reform and opening up brought both new opportunities and severe challenges to the state-run studios and centralized distribution system. The tension between politics, cultural policy, and films was relaxed, allowing more diversified and individualized artistic expression. The liberalized film policy revived the film market. Film directors contributed to the free and versatile advancement in filmmaking from various aspects, and film production reached its golden age by the mid-1980s. ${ }^{66}$

The reform mainly took place to fix the unreasonable purchase arrangement between state-owned studios and the $\mathrm{CFC}$ and revenue/profit sharing ratios among the CFC and its local branches and screening units. ${ }^{67}$ First, there were growing conflicts between the state-owned studios and the uniform distribution system and pricing mechanism controlled by the CFC. In fact, the CFC had always purchased movies from state-owned studios at a fixed price from the 1950s to 1979, regardless of the quality and the theatrical revenue of the individual film. ${ }^{68}$ However, with rising production costs and filming infrastructure costs, the profits that the studios could retain were squeezed out dramatically. ${ }^{69}$ In addition, film studios received no share from the revenue generated by the repeated distribution of the same film, as

\footnotetext{
${ }^{64} 1944$ Amendment of the Copyright Act of the ROC, Articles 1 (2) and 9(2).

${ }^{65}$ Jin (2014), 103. Zhang (2004), 226. Yin and Ling (2002), 101.

${ }^{66}$ Yin and Ling (2002), 101-142. Lu and Shu (1998), 170-179.

${ }^{67}$ Tang (2009b), 5.

${ }^{68}$ Shen (2005), 203.

${ }^{69} \mathrm{Xu}$ and Shi (2007), 41.
} 
the CFC bought out the copyright. ${ }^{70}$ Therefore, the pricing mechanism switched in the 1980s from a fixed buyout price to a floating price (RMB 9000 per copy times the number of copies distributed), and the studios retained the copyright in feature films themselves for repeated distribution and screening. ${ }^{71}$

Secondly, the average sharing ratio of the box office revenue between the local distribution branches, which were under dual supervision of both the CFC and local cultural departments, and the CFC was raised to 3:7 in 1979, twice as much as it was in the 1960s, and the profit-sharing ratio of the local distribution branches and screening units, which were established with the financial support of local distribution branches and local financing, with the local cultural departments was raised to 8:2 in support of the reconstruction and enhancement of the local film projection infrastructures. ${ }^{72}$ Lastly, a floating price mechanism for movie tickets was allowed for the first time in 1985, after having been kept in the range of RMB 0.2 to 0.35 for 35 years. $^{73}$

The measures mentioned above were merely partial adjustments and were unable to solve the institutional defects of the planned economy. The unified cinema system was still of an actively administrative nature and failed to optimize the allocation of resources and interests. ${ }^{74}$ The 16 state-owned studios still monopolized the production of feature films. ${ }^{75}$ It is true that, since cinema was redefined as an industry rather than a government sector and the state funding for film production was stopped in 1984, the state-owned studios were forced to raise funds for film production on their own through bank loans and to assume sole responsibility for profits or losses. ${ }^{76}$ However, a sudden disintegration of the state-funded production model that had lasted for 30 years $^{77}$ could hardly achieve a successful transition to a profitoriented industry, when its deficiencies such as overstaffed structure ${ }^{78}$ remained unsolved, the necessary mechanism of market competition missing, and the statemonopolized distribution and multilayer exhibition system unchanged.

Moreover, the development of new media technology and the market competition with other cultural and entertainment industries exacerbated the difficulties of the film industry. The CFC had run at a massive loss from 1981 to 1984 on the

\footnotetext{
${ }^{70} \mathrm{Xu}$ and Shi (2007), 41.

${ }^{71}$ Ministry of Culture, (Document No. 1558), 1980. Liu (2015), 108.

${ }^{72}$ State Council, Report on the Reform of the Film Distribution and Exhibition Management System, Guo Fa [1979] No. 198, 01.08.1979. Liu (2015), 109. Prior to the Cultural Revolution, the local distribution branches received $8-15 \%$ of the distribution revenue on average in the 1960 s. Liu (2009), 11.

${ }^{73}$ Tang (2009b), 5. Liu (2015), 111.

${ }^{74}$ Jin (2014), 110-111. Tang (2009b), 5-6. Liu (2015), 108-110.

${ }^{75} \mathrm{Jin}$ (2014), 108.

${ }^{76}$ CCCPC, Decision Concerning the Reform of the Economic System, 20 October 1984. Liu (2015), 109.

${ }^{77}$ Jin (2014), 110-111.

${ }^{78} \mathrm{Ji}$ (1999), 343.
} 
distribution of domestic films. ${ }^{79}$ In particular, the rapid rise of television, KTV, and the home video industry hit the movie market badly and diverted hundreds of millions of audience members. ${ }^{80}$ In response, film studios started producing entertainment films in 1988 in the hope of a fast and high return on investment in face of huge market and financial pressure. ${ }^{81}$ In addition, special state funding was established to promote the production of mainstream films. ${ }^{82}$

In terms of management of the film industry, a couple of administrative adjustments were made. In dealing with the sexual, violent, and other types of adult content in films, the Ministry of Radio, Film, and Television (MRFT) issued detailed measures and rating criteria to classify films based on the content suitability for children under 16 years old. ${ }^{83}$ As co-production of films with foreign investment became popular after the end of state-funded film production in 1984, oversight over film coproduction was strengthened by the review and approval process. ${ }^{84}$ From 1986 onward, the CFB and CFC were put under the administration of the MRFT, while local branches of the CFC remained under the supervision of the local cultural departments until 1993. ${ }^{85}$ However, while the film market in the 1980s was flooded with pirated videos and VCD of foreign films and TV series, the market management under multiple jurisdictions of the MRFT, Ministry of Culture, and General Administration of Press and Publication ${ }^{86}$ failed to rectify market disorder, which in turn triggered the legislation of copyright law and film regulations in the 1990s.

\footnotetext{
${ }^{79} \mathrm{Ji}$ (1999), 228.

${ }^{80}$ From 1984 to 1985 alone, the number of movie viewers dropped sharply to 5.2 billion; see Jin (2014), 110-111.

${ }^{81} \mathrm{Lu}$ and Shu (1998), 192-193. Just in 1988, 60\% of the films produced were commercial entertainment films. Jin (2014), 14.

${ }^{82}$ MRFT and Ministry of Finance, Provisional Measures Concerning the Use and Management of the Special Fund for the Development of National Cinemas, 19 March 1991. Liu (2015), 110; Lu and Shu (1998), 180-185; Jin (2014), 115-116.

${ }^{83}$ MRFT and CFC, Management Measures Concerning Films Unsuitable for Exhibition to Children, Guang Fa Ying Zi [1989] No. 824, 2 November 1989; Notification of the MRFT concerning the Censorship and Rating System for Certain Films, Guang Fa Ying Zi [1989] 201, 25 March 1989. Liu (2015), 111.

${ }^{84}$ Publicity Department of the CCCPC, MRFT and General Administration of Customs, Notification to Further Strengthen the Management of Film Production with Foreign Cooperation, Guang Fa Wai Zi [1989] No. 190, 23 March 1989, Liu (2015), 110.

${ }^{85} \mathrm{Jin}$ (2014), 111. This twisted administrative management regime was rooted in the competing interests among different administrative departments. The revenue of local film distribution and exhibition consisted of the biggest financial source for local cultural departments, which was then used to support subsidies for other cultural sectors in the region. Therefore, they refused to give the administrative power back to the MRFT. Ji (1999), 234.
}

${ }^{86}$ Tang (2009a), 281. 


\subsection{Cinema Marketization}

The establishment of the so-called socialist market economy with Chinese characteristics has opened up full-scale legal and institutional reform of cinema and led to transition to its marketization, which inevitably has been accompanied by conflicts, disorder, and crisis due to the long-existing marriage between films and politics and the state monopoly and administrative control over filmmaking.

\subsubsection{The 1990 Copyright Law Set Up Basic Copyright Framework for the Film Industry}

Most significantly, the PRC adopted its first copyright law in 1990, and a basic copyright framework was thus set up for the film industry. ${ }^{87}$ Notably, the copyright system in China is neither a pure author's rights system nor a copyright system, but of a hybrid, pragmatic, and issue-based nature. This nature is critical to the understanding of film copyright in China. For the subject matter, under great influence from the German author's right system, ${ }^{88}$ the Chinese Copyright Law expressly listed "original films" as a category of works eligible for copyright protection, ${ }^{89}$ while the producers of unoriginal "video recordings" were only granted neighboring rights protection..$^{90}$ Besides, the specialties of film have been addressed by copyright rules. In dealing with the multiple right holders in film production, special rules for the authorship and ownership in film works were foreseen. For example, a distinction was made between film works and pre-existing works from which the film had been adapted, such as novels or dramatic works. To protect film producers' substantial investment and to guarantee a full and active commercialization of film, the authors' moral rights in pre-existing works were restricted. Article 13 Implementing Regulations (IR) 1991 stated, where the copyright owner has authorized the film adaption based on his or her work, that permission to make necessary alteration should be implied, in so far as such alteration does not distort or mutilate the original work. In addition, authors of those works that were included in a

\footnotetext{
${ }^{87}$ Standing Committee of the National People's Congress, Copyright Law of the PRC [CL 1990], issued on 7 September 1990, effective 1 June 1991. This Chinese Copyright Law has been revised twice in 2001 and 2010, respectively. For a comphensive overview of the modifications made in the 2001 revision, see Li and Zhou (2001), 1-23. The 2010 revision was due to the failure on a WTO dispute between the US and China for China not protecting audiovisual works with ilicit or immoral content and those pending content review. WTO, China-Measures Affecting the Protection and Enforcement of Intellectual Property Rights: Report of the Panel, WT/DS326/R (26 January 2009). For an overview of this issue, see Zhang and $\mathrm{Li}$ (2015).

${ }^{88}$ The German Copyright Act makes a distinction between original film works ( $\S 2$ I lit.6 and 2 II) and unoriginal moving images ( 95 ).

89 "Cinematographic, television and video works" in Article 3 No. 5 of the CL 1990. The legal definition was given in the Implementing Regulations of the Copyright Law of the PRC [IR 1991] issued by National Copyright Administration, 30 May 1991, Article 4 No. 9.
}

${ }^{90}$ Article 41 I of the 2001/2010 CL, previously in Article 39 I of CL 1990. 
cinematographic work but can be exploited separately, such as a script, music, etc., were allowed to exercise their copyright in such works independently. ${ }^{91}$

Concerning the authorship of cinematographic works per se, the director, scriptwriter, lyricist, composer, cameraman, and other authors were expressly identified as authors of a cinematographic, television, or video work and enjoy the right of authorship. ${ }^{92}$ However, instead of strictly following the German author's rights principle, ${ }^{93}$ the film producer, primarily the state-owned film studios, was designated as the initial copyright owner of film works in China, ${ }^{94}$ partly referencing the US work-for-hire doctrine..$^{95}$ The film producer enjoyed all other copyrights vested in the cinematographic works, including the economic rights, which are subject to limitations and exceptions. ${ }^{96}$ While the economic rights of publication, exploitation, and remuneration in cinematographic works last for 50 years after the first publication, ${ }^{97}$ the remaining moral rights therein remained perpetual and inalienable, ${ }^{98}$ quite similar to the French approach. ${ }^{99}$

Indeed, the CL 1990 neither spelt an end of the state-monopolized film production and distribution system overnight nor eradicated the problem of piracy once and for all. Nonetheless, it was vital for the film industry, because it for the first time confirmed in the form of law that the film studios as the film producers should be the copyright owner of films they produced and enjoy the proprietary rights of exploitation and receiving remuneration derived from films. As a brave first step, the CL 1990 at least provided the essential legal basis for the film copyright owner to fight against piracy, administrative interference, and other giant copyright exploiters. For example, national television stations and broadcasting organizations used to broadcast films even before their public screening, and acquired very well-paid advertising revenues, but returned only a pitiful portion thereof to film studios, as the administrative authorities had treated the issue as no more than putting the money from one's right pocket into the left. Article 44 CL 1990 at least provided the film studios with the specific legal basis to grant the broadcasting right and claim fair and reasonable royalties from national television stations and broadcasting organizations. ${ }^{100}$

\footnotetext{
${ }^{91}$ Article 15(2) CL 1990.

${ }^{92}$ Article 15(1) CL 1990.

${ }^{93}$ The author's rights principle (Schöpfersprinzip) was expressly recognized by $\S 7$ of German Copyright Act.

${ }^{94}$ Article 15(1) CL 1990.

${ }^{95} 17$ USC $\S 101$.

${ }^{96}$ Article 22 CL 1990.

${ }^{97}$ Article 21(3) CL 1990.

${ }^{98}$ Article 20 CL 1990.

${ }^{99}$ Article L 121-1 French IPC.

${ }^{100}$ According to Article 44 CL 1990, a television station which broadcasts a cinematographic, television, or video work produced by others should obtain permission from, and pay remuneration to, the producer of the cinematographic, television, or video work. This was certainly a big favor for film studios in comparison to Articles 40(2) and 43 CL 1990, where the TV stations had statutory licensing in the exploitation of other types of published works for the production of a radio or television program and had no obligations of securing permission or paying for broadcasting a published sound recording for noncommercial purposes.
} 


\subsubsection{Further Reform in Film Distribution, Import, and Production}

In implementing the CL 1990, the right to distribute and export feature films was given back to the studios, so that studios were able to conclude distribution contracts directly with local distributors, removing the intermediate link of the CFC. ${ }^{101}$ Previously, a four-layer distribution network had been in operation from 1949 to 1992: the CFC $\rightarrow$ provincial level $\rightarrow$ municipal level $\rightarrow$ county level. ${ }^{102}$ The unified purchase and distribution system monopolized by the CFC was finally revoked in 1993. However, given that there was only one distribution channel within each province at that time, the studios then had to sell feature films to 31 local distributors at the provincial level separately. ${ }^{103}$ The monopoly of the provincial distributors was abolished in 1994, as studios were allowed to sell films to local distributors at all levels ${ }^{104}$ in the hope that competitive distribution would reduce local access barriers and transaction costs. However, such measures were not as effective as expected, primarily because local distributors and theaters remained state-owned companies under the direct administrative control of the provincial distributors.

The CFC started to import ten foreign films every year from 1994 onward to revive the ailing domestic box office and shared net box office revenues of imported films with foreign film producers and the provincial and municipal distributors and exhibitors. ${ }^{105}$ The strategy to import ten foreign blockbusters did boost the sluggish film market, as they immediately became the major contributors to the domestic box office revenue despite the small quota. For example, Titanic alone hit RMB 360 million, accounting for $40 \%$ of total box office revenue for the whole year of 1997, a record held for more than 10 years until Avatar in $2010 .{ }^{106}$ In addition to the protective measure of the import quota, the screening time of imported films was limited to no more than one-third of the overall screening time to protect domestic films. ${ }^{107}$

With regard to film production, efforts were made to prevent the already stagnant domestic film production from being completely knocked down by imported blockbusters. The reform of feature film shooting took place in the mid-1990s. In addition to the first expanding film production from 16 approved national studios to include certain state-owned film studios at the provincial level in 1995, private entities were allowed to be named as "joint producer" if their investment in feature film production accounted for more than $70 \%$, although still without an independent filmmaking

\footnotetext{
${ }^{101}$ MRFT, Several Opinions to Further the Contemporary Reform of the Cinema System, Guang Fa Ying Zi [1993] No. 3, 5 January 1993. Tang (2009a), 282.

${ }^{102}$ SARFT and Ministry of Culture, Implementation Rules for the Reform of the Film Distribution and Exhibition Regime, Guang Fa Ban Zi [2001] No. 1519, 18 December 2001. Liu (2012a), 4.

${ }^{103}$ Weng (2009), 57.

${ }^{104}$ MRFT, Notification on the Further Deepening Reform of the Cinema System, Guang Dian Zi [1994] No. 348, Weng (2009), 57. Tang (2009a), 277, Footnote 1.

${ }^{105}$ The import quota of ten revenue-sharing films lasted from 1994 to 2000, with the internationally conventional sharing ratio of $35 \%$ for $\mathrm{CFC}, 17 \%$ for foreign film producers, and $48 \%$ for provincial and municipal distributors and exhibitors. Jin (2014), 129. Weng (2009), 57-58.

${ }^{106} \mathrm{Jin}$ (2014), 129-130.

${ }^{107} 1996$ Regulation on Administration of Films, Article 45(2).
} 
permit. ${ }^{108}$ Then in 1997, all state-owned provincial film studios, certain qualified municipal film studios, TV stations, and TV series makers were allowed to apply for the single feature film production license. ${ }^{109}$ However, domestic film production still heavily relied on state subsidies. ${ }^{110}$ More than $70 \%$ of the domestic films could hardly recover the production costs, let alone compete with imported blockbusters. As a result, only about 40 feature films were produced from 1997 to $1998 .{ }^{111}$

\subsubsection{A Comprehensive Prior Approval System for Films}

Due to domestic social and political unrest and international pressure, the government re-emphasized the stability of the social and political structure ${ }^{112}$ and reinforced the control of films by administrative and economic means after the 1996 National Cinema Conference in Changsha. ${ }^{113}$ Above all, the State Council issued the first special regulation on films in 1996 - the Regulation on Film Administration ${ }^{114}$ - to establish a comprehensive prior approval system for production, distribution, exhibition, import, and export of films, including the conditions and process for approval and legal consequences of approval and disapproval. Moreover, the ex ante and ex post film censorship system and explicit criteria for content review were put in place. ${ }^{115}$ In particular, film scripts must be filed on record before shooting, the completed film submitted for content review, and the Film Public Screening Permit be issued upon approval by the censors. ${ }^{116}$

In addition to administrative intervention, the government also subsidized the 9550 Project of producing 50 mainstream films in 5 years from 1996 to 2001 to strengthen the ideological and propaganda function of cinema. ${ }^{117}$ Again in 1998, special funding for the production of films on important subjects was provided for the celebration of the 50th anniversary of the founding of the PRC. ${ }^{118}$ Moreover, the mainstream ideology became a more and more important criterion for the three most prestigious film awards in China, namely, the "Huabiao Awards," "Golden Rooster Awards," and "Hundred Flowers Awards."119

\footnotetext{
${ }^{108}$ MRFT, Rules for the Reform on Feature Film Shooting Management, Guang Fa Ying Zi [1995] No. 001, 05 January 1995.

${ }^{109}$ Tang (2009a), 285.

${ }^{110}$ Tang (2009a), 285.

${ }^{111}$ Zhang (2004), 284; Yin (2001), 27 and 31-32. Liu and Wang (2012), 5.

${ }^{112}$ Yin and Ling (2002), 160.

${ }^{113}$ Yin and Ling (2002), 199.

${ }^{114}$ State Council, Regulation on Film Administration, [1996] No. 200, 19 June 1996. It was revised in 2001, [2001] No. 342, 25 December 2001.

${ }^{115} 1996$ Regulation on Film Administration, chapter 3; MRFT, Rules for Film Censorship, [1997] No. 22, 16 January 1997.

1161996 Regulation on Film Administration, Articles 25-28.

${ }^{117}$ Yin and Ling (2002), 199.

${ }^{118}$ Tang (2009a), 285.

${ }^{119}$ Yin and Ling (2002), 153-154.
} 


\subsection{Industrialization}

\subsubsection{Further Liberalization of Import and Distribution of Foreign Films}

Since the start of the twenty-first century, the industrialization of Chinese cinema has made significant progress. Far-reaching reform has continued. The film import quota of foreign movies increased from 10 to 20 each year in 2001 when China acceded to the WTO. Under pressure from Hollywood, the annual quota was raised to 34 in 2012, 14 of which must be 3D or IMAX films. The revenue-sharing ratio of the American companies increased from $13 \%$ to $17.5 \%$ to $25 \% .{ }^{120}$ Besides, with the launch of the Huaxia Film Distribution Co. in 2003, the film distribution market of foreign films turned from monopoly by the $\mathrm{CFC}^{121}$ to duopoly. To date, CFC and Huaxia remain the only two that possess SARFT-conferred licenses to distribute foreign films in China.

\subsubsection{Nationwide Cinema Chains}

A new cinema chain regime that built several movie theater chains across different regions was established in $2002^{122}$ to further reduce the transaction costs created by unnecessary intermediaries within the same region and bring competition in crossregion distribution. ${ }^{123}$ Further, it was finally possible in 2003 for private companies to operate as legitimate independent distributors, after 7 years as agents of such distributors. ${ }^{124}$ Private companies are currently the leading force in distributing domestic films. In 2015, the top ten private distribution companies had an $84.9 \%$ share of the market in domestic film distribution, contributing RMB 22.98 billion in box office revenue, $52.1 \%$ of the total box office revenue in $2015 .{ }^{125}$ The M\&A and restructuring from 2004 to 2008 have formed nationwide cinema chains and led to concentration. ${ }^{126}$ The booming screening market and the intense competition have created a tremendous driving force for the expansion of cinema chains to cover small and medium cities and rural areas. ${ }^{127}$

\footnotetext{
${ }^{120}$ China-US Memorandum of Understanding resolving the WTO film-related issues, Geneva, 25 April 2012.

${ }^{121}$ SARFT and Ministry of Culture, Implementation Rules for the Reform of the Film Distribution and Exhibition Regime, Guang Fa Ban Zi [2001] No. 1519, 18 December 2001. Weng (2009), 58; Liu (2012b), 8 .

${ }^{122}$ State Administration of Radio, Film, and Television ("SARFT") and Ministry of Culture, Implementation Rules for the Reform of the Film Distribution and Exhibition Regime, Guang Fa \ Ban Zi [2001] No. 1519, 18 December 2001.

${ }^{123}$ Weng (2009), 58.

${ }^{124}$ Although the 1996 Regulation on Administration of Films allowed private capital to be invested in the film distribution channel, it was not until 2003 that the legitimate status of the seven private companies was confirmed as independent distributors for the first time. Weng (2009), 59.

${ }^{125}$ Wisdomfish, China's Film Industry Annual Report 2015, 1.1.1 and 1.1.5.

${ }^{126}$ Tang (2009a), 288-289. Liu (2012a), 6-7.

${ }^{127}$ Liu (2012a), 4-5.
} 
In addition, a new era of digital film distribution started in 2004 when SARFT announced the development pillars of film digitization from 2004 to 2010 to promote the digitization of film production, to establish the digital distribution network, to improve the construction of digital cinemas, and to accelerate the localization of the manufacture of related equipment and software. ${ }^{128}$ In exploring the multimedia network of distribution via television, Internet and mobile terminals, and theatrical distribution, China's cinema is approaching the age of megaindustry. ${ }^{129}$ The number of cinema screens increased to 41,179 in 2016 , which was for the first time more than those in the USA. ${ }^{130}$

\subsubsection{Further Liberalization of Film Production}

Most importantly, the threshold for filmmaking was lowered, and investment sources were diversified to allow private and foreign capital. ${ }^{131}$ In particular, the 2001 Regulation on Film Administration provided non-film studios with the Single Film Production Permit, so that private entities could obtain independent qualification for filmmaking ${ }^{132}$ and soon became key players in domestic film production. In 2002 alone, five private companies obtained 58 permits, and 32 out of the 100 domestic films produced in that year came from private companies such as Huayi Brothers Media Corporation and Beijing New Pictures. ${ }^{133}$ Besides, the restrictions on Sino-foreign film co-production were further relaxed. ${ }^{134}$ Also, the 2006 Rules for Film Script (Outline) Filing and Film Administration ${ }^{135}$ simplified the script review and filing process, as the film script or outline merely needed to be filed for the record, only the completed films had to go through the review and approval process, and the centralized film censorship power was partly transferred to the provincial level. This film censorship system has been generally reconfirmed by the 2016 Film Industry Promotion Law. ${ }^{136}$

${ }^{128}$ SARFT, Development Outline of Film Digitization, Guang Fa Ying Zi [2004] No. 257, 18 March 2004.

${ }^{129}$ Weng (2009), 59.

${ }^{130}$ Wisdomfish, China's Film Industry Annual Report 2016, 2.1.1. Entgroup, China Film Industry Report 2015-2016 (In Brief), 5.1.1.

${ }^{131}$ Yin and Liang (2012), 5. Ministry of Commerce and Ministry of Culture, Provisional Rules for Foreign Investment in Cinemas, [2003] No. 21, 25 November 2003; SARFT and Ministry of Commerce, Provisional Rules on the Entry Criteria for Operating Film Enterprises, [2004] No. 43, 10 October 2004.

${ }^{132}$ State Council, Regulation on Administration of Films, [2001] No. 342, 25 December 2001, Article 16. SARFT, Interim Provisions on the Access Qualifications for Film Production, Distribution and Exhibition, [2003] No. 20, 29 October 2003, Article 3.

${ }^{133}$ Yin and Liang (2012), 7.

${ }^{134}$ SARFT, Measures for Administration of Sino-Foreign Film Co-Production, [2003] No. 19, 10 August 2003. For rules governing co-production between Mainland China and Hong Kong, see 1.2. ${ }^{135}$ SARFT, Rules for Film Script (Outline) Filing and Film Administration, [2006] No. 52, 22 May 2006.

${ }^{136}$ Standing Committee of the National People's Congress, Film Industry Promotion Law, Order No. 54 of the President, 7 November 2016, chapter 2. 
The abovementioned macro reforms improved the productivity and market adaptability of Chinese film production. The number of produced feature films increased ten times from around 40 in 1997 to 402 in 2007, and annual production ranked third worldwide after the USA and India. ${ }^{137}$ However, the growth rate of film production has slowed down due to the saturated screening market starting in $2008 .{ }^{138}$ While the rapid increase in film production from 2002 to 2011 indicated robust market demand and the optimism of investors, blind investment in films and unprofessional filmmaking by small- and medium-sized private enterprises (SME) became a serious problem. For example, SME produced 354 of 558 films (63.44\%) in 2011 , only $13.84 \%$ of which were released in movie theaters, and only one of which generated box office revenue above RMB 100 million. ${ }^{139}$

Therefore, the industrial reform in film production was then transformed and continues to focus more and more on enhancing the quality, market performance, and diversity of feature films, rather than on increasing the quantity. As a result, seven major state-owned film groups that integrated film production, distribution, and exhibition channels across different regions were established between 1999 and 2008. ${ }^{140}$ After determined and dedicated efforts for a decade since 2002, private film studios were facilitated by the capital market and became core players in domestic film production. ${ }^{141}$ In 2012, large private film studios produced only 22 films, yet had a high theatrical release rate of $95.45 \%$, and seven films generated box office revenue above RMB 100 million. ${ }^{142}$ Currently, films produced by large state-owned film group corporations, large private film studios, and films co-produced by domestic and foreign capital are the main contributors to domestic box office revenues.

From 2002 to present, industrial standards and market order have been built up through the rule of laws and regulations, rather than through administrative instructions and cultural policies. In 2006, the film industry was named the number one of the nine critical cultural industries by the Culture Development Program of the 11th Five-Year National Plan (2006-2010). ${ }^{143}$ In 2009, the revitalization of the film industry became one of the national strategic development programs. ${ }^{144}$ In 2010, a new objective was set up to realize the historical transformation from a large-scale to a robust and competitive Chinese cinema industry. ${ }^{145}$ In the same year, the total

\footnotetext{
${ }^{137}$ Yin and Liang (2012), 5-6.

${ }^{138}$ Yin and Liang (2012), 6.

${ }^{139}$ Liu and Wang (2012), 11 and 13.

${ }^{140}$ SARFT and Ministry of Culture, Several Opinions on Further Deepening the Reform of the Film Industry, Guang Fa Ying Zi [2000] No. 320, 6 June 2000. Tang (2009a), 287. In particular, the China Film Group Corporation (CFGC) replaced the CFC in 1999.

${ }^{141}$ Yao and Li (2017), 19.

${ }^{142}$ Liu and Wang (2012), 11 and 13.

${ }^{143}$ General Office of the CCCPC and General Office of State Council, "Culture Development Program during the 11th Five-Year National Plan Period" (2006-2010), 13 September 2006.

${ }^{144}$ General Office of the State Council, "Plan on the Reinvigoration of the Cultural Industry", 26 September 2009 .

${ }^{145}$ General Office of the State Council, Guidance Opinions for Promoting the Prosperity and Development of Film Industry, Guo Ban Fa [2010] No. 9, 21 January 2010.
} 
box office revenue of domestic cinema surpassed RMB 10 billion for the first time. ${ }^{146}$ In 2014, favorable economic and tax policies were issued to support further development of the film industry. ${ }^{147}$ Eventually, the 2016 Film Industry Promotion Law confirmed and updated the ongoing development directions of Chinese cinema in the form of law.

\subsubsection{Internet Giants Are Swarming into the Film Industry}

In China, the film industry and other upstream and downstream interested parties are adapting themselves to the digital audiovisual market by resorting to creative market solutions within the copyright regime. A good example is that major Internet giants such as Baidu, Alibaba, and Tencent (the so-called BAT) have been swarming into the film industry, bringing with them big data, technology, funding, platforms, and fundamental changes to audiovisual services, transforming their business models from providing illegal content to legal but free (ad-sponsored) content and to legal and paid premium content. As a result, they not only provide instantaneous access to quality films and make enforcement of copyright against piracy easy but also fundamentally change consumers' behavior and habits in digital content consumption and help to set up an industrial code or self-regulation for the digital film market. $^{148}$

\subsubsection{Film Copyright}

To date, a comprehensive copyright framework in line with the international obligations (concerning cinematographic works and copyright protection in general) has been established. Moreover, copyright enforcement has been further enhanced by the addition of protection for rights management information ${ }^{149}$ and against the circumvention of effective technological measures, ${ }^{150}$ the imposition of criminal liabilities for film piracy that prejudices public interests, ${ }^{151}$ and the clarification of

\footnotetext{
${ }^{146}$ Liu (2011), 17.

${ }^{147}$ Ministry of Finance, the General Administration of Press, Publication, Radio, Film and Television and other Departments, Notice on Several Economic Policies for Supporting Film Development, Cai Jiao [2014] No. 56, 31 May 2014.

${ }^{148}$ This could be an instructive example to overcome the dilemma of copyright enforcement against online piracy. See also Banerjee A (2019), XXX. In this way, the role of video platforms or search engine providers has been changed from pirates or intermediaries to stakeholders. As a result, the copyright enforcement measures are now taken to safeguard their own interests instead of fulfilling legal obligations.

${ }^{149}$ Article 47 No. 7 CL 2001 (currently Article 48 No. 7 CL 2010): anyone who commits any of the following acts of infringement... (7) intentionally deleting or altering the electronic right management information of a work, sound recording or video recording, without the permission of the copyright owner or the administrative regulation.

${ }^{150}$ Article 47 No. 6 CL 2001 (currently Article 48 No. 6 CL 2010): anyone who commits any of the following acts of infringement... (6) intentionally circumventing or destroying the technological measures taken by a right holder for protecting the copyright or copyright-related rights in his work, sound recording or video recording, without the permission of the copyright owner or the owner of the copyright-related rights, unless otherwise provided in law or in administrative regulations.

${ }^{151}$ Article 47 CL 2001 in conjunction with Articles 217 No. (1) and 218 of the Criminal Law, Li and Zhou (2001), 167-187.
} 
calculation methods for damages. ${ }^{152}$ More and more, copyright law is playing a significant role in the furtherance of cinema industrialization. To avoid overly complicated rules on film authorship and ownership, Article 15(1) CL 2010 makes some modifications and provides that the film producer is the initial and sole copyright owner who can exercise and enforce the copyright attached to the film with full competence, except for the right of authorship. The exclusive rights of the film producer expanded to include the rental right, ${ }^{153}$ the right of screening, ${ }^{154}$ and the right of communication to the public through the information network. ${ }^{155}$ In addition to the right of authorship, the 2001 Copyright Law accorded the authors of cinematographic works the right to receive remuneration. ${ }^{156}$ Nonetheless, physical and online film piracy remains one of the biggest threats to the film industry in China, as box office revenue constitutes "the vast majority" of the total revenue for the film industry. ${ }^{157}$

\section{$5 \quad$ Challenges Ahead}

The initial illustrative listing of copyright-protected works included "cinematographic, television and video works" (Article 3 No. 5 CL 1990). ${ }^{158}$ In addition, those which do not qualify as copyright-protected video works were recognized as "video recordings" and enjoyed neighboring right (Article 39(2) CL 1990). The terms "cinematographic, television, and video works" were replaced by the more generalized term "cinematographic works and works created by a process analogous to cinematography" in 2001, ${ }^{159}$ under the condition that those works were "recorded on a certain medium material." 160 Yet, the filming technology per se should be irrelevant in determining the copyright protection eligibility of a work. ${ }^{161}$ It is therefore proposed in the third draft of the third revision of the Chinese Copyright Law in 2014 to replace the distinction between "cinematographic works and works created by a process analogous to cinematography" and video recordings altogether with a general work category of "audiovisual works" and to abandon the "recorded on a

\footnotetext{
${ }^{152}$ Calculation methods of damage include actual losses, infringer's profits, and statutory damages with a ceiling of RMB 500,000, Article 48 CL 2001 (currently Article 49 CL 2010).

${ }^{153}$ Expressly in Article 10 (1) No. 7 CL 2001/2010, in accordance with Article 11 TRIPS.

${ }^{154}$ Article 10 (10) No. 7 CL 2001/2010.

${ }^{155}$ Article 10 (1) No. 12 CL 2001/2010, in accordance with Article 8 WIPO Copyright Convention (the right of making available to the public).

${ }^{156}$ Article 15 (1) CL 2001/2010.

${ }^{157}$ For studies on copyright enforcement against film piracy, both online and offline, and alternative solutions in practice, see Priest (2006) and (2014).

${ }^{158}$ The illustrative expressions of "cinematographic, television and video works" were initially used in proximity of daily language, Zheng and Pendleton (1991), 76. Zheng CS (2009), $127-128$.

${ }^{159}$ Article 3 No. 6 CL 2001/2010.

${ }^{160}$ Article 4 No. 9 IR 1991, and Article 4 No. 11 IR 2002/2013.

${ }^{161}$ Wang (2015), 107; Li and Xu (2003), 41.
} 
certain medium" requirement. ${ }^{162}$ However, the revision of the Copyright Law does not seem to be high on the agenda of the National People's Congress, and no enactment can be expected in the near future. Currently, some court decisions have set rather high "originality" and "fixation" standards for films, which worries the industry and academics. ${ }^{163}$

Another challenge is how to design the rules of authorship and ownership in film works. There are commonly three approaches in this regard. The first treats a film as a pure authorial work, and the film producer is neither author nor initial copyright owner of the film. For example, the German Copyright Act adopts the general creator's principle and provides no exceptions for film works. ${ }^{164}$ As a result, natural persons who have made intellectually creative contributions to film works should be (joint) authors. With respect to the protection of the film producer, the German Copyright Act merely provides that in cases of doubt, joint authors of the film work should be assumed to have granted the producer of the film the exclusive right to use in all manners the cinematographic work in Article 89(1) and grants the film producer further protection of neighboring rights in video recordings in Article 94.

Alternatively, motion pictures can be considered entrepreneurial works, and the film producer is the sole author and copyright owner. In this regard, the "work made for hire" doctrine is the cornerstone in the US Copyright Act. In particular, $\S 201$ (b) of the US Copyright Act provides that in the case of a work made for hire, the employer or other person for whom the work was prepared is considered the author for purposes of this title, and, unless the parties have expressly agreed otherwise in a written instrument signed by them, owns all of the rights comprised in the copyright. As a result, film producer can be recognized as the initial copyright owner of film and other audiovisual works in the USA.

The third approach recognizes films as "a hybrid of entrepreneurial and authorial works." 165 On the one hand, the British Copyright Act specifies the producer and the principal director as statutory joint authors for films made on or after 1 July $1994 .{ }^{166}$ On the other, where a film is made by an employee in the course of employment, the employer (often the film producer) is assumed to be the first owner of the copyright in the film, subject to any agreement to the contrary. ${ }^{167}$ Hong Kong follows the same rules.

\footnotetext{
${ }^{162}$ Article 5 No. 12, Revision Draft 2014.

${ }^{163}$ For example, (2015) Jin Zi Min Zhong 1818 decision by the Beijing IP Court (decided on March 30, 2018).

${ }^{164}$ The German Copyright Act applies strictly the creator's principle (Schöferprinzip) in Article 7 that only a natural person who actually creates a work can be the author of the work. The creator's principle applies to commissioned works and works made for hire. Dreier/Schulze, UrhG, §7 paras 2,4 , and 7.

${ }^{165}$ Bently and Sherman (2014), 128.

${ }^{166}$ CDPA 1988, ss 9(2)(ab) and 10(1A).

${ }^{167}$ CDPA 1988, s 11(2).
} 
China has chosen the third approach in Article 15 CL 2010. ${ }^{168}$ Article 15(1) specifies the film producer as the statutory copyright owner in cinematographic works and at the same time expressly recognizes the scriptwriter, director, cameraman, lyricist, and composer as film authors. Notably, all three approaches provide merely legal assumption of ownership. However, a single statutory rule such as Article $15(1)$ is questionable, considering that the allocation of copyright in films is mostly dealt with using contractual agreement in practice. Therefore, a flexible legal assumption that prioritizes the contractual agreement among the interested parties on the ownership in films would be more desirable. ${ }^{169}$ In addition, despite the fact that the British hybrid approach is a compromise in compliance with Article 2(1) of the Term Directive, ${ }^{170}$ both German and the US rules of authorship and ownership in film works are consistent with their traditional copyright theories and the existing copyright systems. In comparison, the CL 2010 has already introduced both the rules for works of joint authorship in Article 13(1), like the German approach, and the rules for works made in the course of employment in Article 16, similar to the US and UK approaches. Nonetheless, an additional provision - Article 15 - was made to solely deal with the authorship and ownership issues for film works, which however would cause overlaps and even competing rules in practice. It would be dogmatically clearer and more precise to first resort to the existing rules in line with the copyright theories, and only make an exceptional rule should the application of the existing rules be insufficient or cause confusion. This is undoubtedly a higher requirement in terms of legislative wisdom and technique.

\section{References}

Bently, L., \& Sherman, B. (2014). Intellectual Property Law. Oxford: Oxford University Press. Cheng, J. H., Li, S. B., \& Xing, Z. W. (1998). The development history of the Chinese film (Vol. 1). Beijing: China Film Press (in Chinese).

Hu, J. B., \& Yao, X. M. (1989). Film policy and its formulation of the New China, 1 Contemporary Cinema 7 (in Chinese).

\footnotetext{
${ }^{168}$ Article 15 provides: (1) The copyright in a cinematographic work or in a work created by a process analogous to cinematography shall be enjoyed by the producer of the work, while its scriptwriter, director, cameraman, lyricist, composer, and other authors shall enjoy the right of authorship therein and shall be entitled to receive remuneration in accordance with the terms of the contracts concluded between them and the producer. (2) The authors of the script, the musical works, and the other works which are included in a cinematographic work or in a work created by a process analogous to cinematography and which can be exploited separately shall be entitled to exercise their copyright independently.

${ }^{169}$ Bently and Sherman (2014), 129.

${ }^{170}$ Directive 2006/116/EC of the European Parliament and of the Council of 12 December 2006 on the term of protection of copyright and certain related rights. Article 2(1) prescribes: 1 . The principal director of a cinematographic or audiovisual work shall be considered as its author or one of its authors. Member States shall be free to designate other co-authors.
} 
Ji, H. (1999). Ji Hong's selected works of film economics. China Federation of Literary and Art Circles Publishing House (in Chinese).

Jin, Y. H. (2014). Cultural policy of the PRC and the development of the contemporary Chinese cinema. Guangzhou: World Publishing Corporation (in Chinese).

Kamina, P. (2016). Film copyright in the European Union (2nd ed.). Cambridge: Cambridge University Press.

Li, D. X. (2017). Film distribution and projection networks in the PRC: A historical study. Journal of Zhejiang University of Media and Communications, 24(3), 2 (in Chinese).

Li, S. Y., \& Hu, J. B. (1996). Chinese silent film history. China Film Press (in Chinese).

Li, M. D., \& Xu, C. (2003). Copyright law. Beijing: Law Press China (in Chinese).

Li, S. D., \& Zhou, X. (2001). Guidance of the revision of copyright law of PRC. Beijing: Intellectual Property Publishing House (in Chinese).

Liu, Y. (2009). A research overview of the film management system in the first seventeen years, (2009) 13 Movie Literature 7 (in Chinese).

Liu, H. W. (2011). The analysis report of Chinese film enterprise in 2010. 3 Contemporary Cinema 16 (in Chinese).

Liu, H. W. (2012a). Review of ten years reformation of China cinema line system, (2012) 6 Contemporary Cinema 4 (in Chinese).

Liu, H. W. (2012b). China-US film agreement: Impact and response, (2012) 4 Film Art 5 (in Chinese).

Liu, Y. (2015). The Chinese film system research (1976-1993), (2015) 1 Contemporary Cinema 105 (in Chinese).

Liu, H. W., \& Wang, C. C. (2012). The analysis of the transition of China film production, (2012) 7 Contemporary Cinema 10 (in Chinese).

Lu, H. S., \& Shu, X. M. (1998). China film history. Beijing: Culture and Art Publishing House. (in Chinese).

Priest, E. (2006). The Future of Music and Film Piracy in China. Berkeley Tech L J, 21, 795.

Priest, E. (2014). Copyright extremophiles: Do creative industries thrive or just survive in China's high-piracy environment? Harvard Journal of Law \& Technology, 27(2), 467.

Priest, E. (2015). Copyright and free expression in China's film industry. Fordham Intell Prop Media \& Ent L J, 26(1), 1.

Ricketson, R., \& Ginsburg, J. C. (2005). International copyright and neighbouring rights: The Berne Convention and beyond (Vol. 1). Oxford: Oxford University Press.

Shen, Y. (2005). History of the Chinese film industry China. Film Publisher (in Chinese).

Tang, R. (2009a). Performance analysis of the Thirty Years' film system reform. In B. G. Cui (Ed.), Report on Development of China's Media Industry (p. 275). Beijing: Social Sciences Academic Press. (in Chinese).

Tang, R. (2009b). Study on the Chinese Film System Reform within the 30 Years of the Economic Reform, (2009) 2 Modern Media 5 (in Chinese).

Wang, C. G. (1997). KMT Film Censorship System in the early 1930s, (1997) 3 Film Art 60 (in Chinese).

Wang, C. G. (2001). The Origins of the Film Censorship System in the Republic of China, (2001) 3 Modern History Research 204 (in Chinese).

Wang, C. G. (2002). Wartime Film Censorship in the Japanese occupied areas, (2002) 1 Kang Ri Zhan Zheng Yan Jiu 24 (in Chinese).

Wang, C. G. (2006). An Investigation of the Central Film Censorship Committee (1934-1937) (2006) (Summer) Social Sciences in China 141 (in Chinese).

Wang, Q. (2015). Copyright Law. Beijing: Renmin University Press (in Chinese).

Weng, L. (2009). The change of distribution of Chinese Film since 1949, (2009) 12 Contemporary Cinema 56 (in Chinese).

Xu, S. C., \& Shi, C. (2007). A Bitter Controversy over Film Distribution Regime (2007) 6 Popular Cinema 41 (in Chinese).

Yao, S. G., \& Li, G. C. (2017). The industrial and market development of the Chinese Cinema since 2003, (2017) 2 Hundred Schools in Arts 10 (in Chinese). 
Yin, H. (2001). At the turn of the century: The memo of the Chinese Cinema in 1990s. Contemporary Cinema, 1: 23 (in Chinese).

Yin, H., \& Liang, J. J. (2012). Ten years reformation of China film production system. Contemporary Cinema, 7, 4 (in Chinese).

Yin, H., \& Ling, Y. (2002). A history of Chinese Cinema: 1949-2000 (in Chinese).

Zhang, Y. J. (2004). Chinese National Cinema. (New York/London: Routledge, 2004).

Zhang, W. J., \& Li, Y. B. (2015). Content review and copyright protection in China - After the 2009 U.S. v. China WTO Panel Ruling. J Copyright Soc'y USA, 62(3), 437.

Zheng, C. S. (2009). Copyright law, Vol. 1 and 2 (rev edn, Beijing: Renmin University Press (in Chinese).

Zheng, C. S., \& Pendleton, M. D. (1991). Copyright law in China. (CCH Australia 1991).

Zhou, L., \& Li, M. S. (Eds.). (1997). Research references on Chinese copyright history. Beijing: China Fang Zheng Publishing. (in Chinese).

Open Access This chapter is licensed under the terms of the Creative Commons Attribution 4.0 International License (http://creativecommons.org/licenses/by/4.0/), which permits use, sharing, adaptation, distribution and reproduction in any medium or format, as long as you give appropriate credit to the original author(s) and the source, provide a link to the Creative Commons license and indicate if changes were made.

The images or other third party material in this chapter are included in the chapter's Creative Commons license, unless indicated otherwise in a credit line to the material. If material is not included in the chapter's Creative Commons license and your intended use is not permitted by statutory regulation or exceeds the permitted use, you will need to obtain permission directly from the copyright holder. 